\title{
Natural Killer Cell
}

National Cancer Institute

\section{Source}

National Cancer Institute. Natural Killer Cell. NCI Thesaurus. Code C12536.

Natural killer cells are cells that resemble large granular lymphocytes. They do not express markers of either T or B cell lineage. They are positive for CD16, CD56, and CD 94. These cells do possess Fc receptors for IgG and can kill target cells using antibodydependent cell-mediated cytotoxicity. They can also use perforin to kill cells in the absence of antibody and killing may occur without previous sensitization. 